\title{
Women Witnesses: Female Role and the Construction of Traditional Samba
}

\author{
Claudia Toldo \\ $\mathrm{PhD}$ in Applied Linguistics \\ Pontifical Catholic University of Rio Grande do Sul \\ Professor and Coordinator of PPGL \\ Doctorate and Mastering in Language Studies, Brazil \\ Débora Facin \\ $\mathrm{PhD}$ in Language Studies \\ University of Passo Fundo (UPF)
}

\begin{abstract}
This paper aims to discuss the role/participation of women in the historical process of consolidating the samba de raiz. For this, the methodological principles that structure the reflection are organized around the notions of testimony and witness (Agamben, 2008) and the necessary relation between language and society (Benveniste, 1968/2006). Under the inspiration of saussurean thoughts about the system, we place ourselves in the field of language as tongue and take it as the norm for all manifestation of language. The woman, since her presence in PequenaÁfrica, was a witness (superstes) of raiz do samba. For this reason, the value of her testimony, which is imprinted in the language, survives even today in Brazilian culture.
\end{abstract}

Keywords: Women. Testimony. Language.Society. Samba de raiz.

\section{First Words}

Rua Visconde de Itaúna, 117, Pequena África ${ }^{1}$, Rio de Janeiro. This is the place of a lofty subject in the world of samba, of a feminine strength and-for us-a peculiar witness of the culture that agonizes, but doesn't die: Mama Ciata. According to poet Vinicius de Moraes, "[ ...] samba is Carioca and wasn't born in the favelas," it was born "[...] in the courtyard in front of the famous Mama Ciata's single-door-and-window shack" (Moraes, 2008, p. 11). Pequena África and Mama Ciata's Home are spaces where the cultural values therein constructed explore the feminine gender of their names. Pequena África and Mama Ciata's Home are names which highlight peculiar scenarios deriving from a Diaspora, setting the beginning of Carioca urban samba. They are locus of enunciation built upon traditional samba. Thus, we begin reflecting on the participation of women in Brazilian historical, literary, and musical processes by analyzing their contribution during late nineteenth century and twentieth century, considering their role and their production in History and Literature, and their legacy alike - a testimony of their assertion in the public sphere. Herein, through traditional samba, which is sung by language.

Thus, while proposing an investigation on women's role in the consolidation of traditional samba, we do not target a sociological approach. Language is the means we use to organize our discussion, because language is the only means able to interpret society, because society is within language, because it is language which enables witnessing society, because it is language which enables the testimony of Baiana Mamas who have undoubtedly founded Pequena África's culture - the main scenario of the genesis of Carioca samba. Understanding Benvenistian premise that society is within language, it is inevitable to interpret any social fact outside linguistic expressions. We believe society in its fundamental meaning is built within collectiveness, such as language whose system is made solid in collectiveness. In this sense, language and society taken at the fundamental level consist of unconscious realities and, in a correlation of necessity, represent the form and the spirit of man - that who speaks.

\footnotetext{
${ }^{1}$ Designation of the space where the community coming from the State of Bahia (Baiana) settled down in the City of Rio de Janeiro from 1870 on. According to Lopes and Simas' definition (2017, p. 220), “[...] the region would go from the surroundings of the ancient Praça Onze until next to current Praça Mauá, [...] the ancient districts and parishes Cidade Nova, Santana, Santo Cristo, Saúde and Gamboa.” [a região se estendia dos arredores da antiga Praça Onze até as proximidades da atual Praça Mauá, [...] as antigas localidades e freguesias da Cidade Nova, de Santana, do Santo Cristo, da Saúde e da Gamboa]. Pequena África was mainly the space of "[...] multiple expressions of African-Brazilian culture, from music to religion." [múltiplas expressões da cultura afro-brasileira, da música à religião]. This iswhere samba was perpetuated in its urban form.
} 
If man is defined within language; furthermore, if language before serving the purpose of communication serves that of living, discussing from linguistic reality women's role as witnesses of traditional samba is not only timely, but also necessary. It is necessary because when enunciated language in samba reveals specific experiences in such culture. It is necessary because language does indeed reveal culture as values transform and receive new meanings. After all, human values of man in society are imprinted in language. And that is because understanding language and society are related in "synchronicity and in semiological relationship," this implies two propositions: "language is the interpretant of society; society is within language" (Benveniste, 1968/2006, p. 97).

When Benveniste approached the necessary relationship between language and society in Convegno Internazionale Olivetti, in October, 1968, (1968/2006, p. 97) he stated: "above classes, above groups and private activities, a cohesive power rules, one that makes a community out of a group of individuals and creates the very own possibility of production and subsistence. This power is language and only language." It means there is a compatible force of identity within multiplicity of human activities in society, constituting culture. Claiming that society is within language implies getting apart from any feeling that places language and society in an independent relationship.

Benveniste (1968/2006) refers to Sapir to reject any conception predicting independence concerning nature of the two systems. Even before Benveniste (1969/2006, p. 61) attribute to language the role of "interpretant of every other linguistic and nonlinguistic systems," Sapir (1969, p. 21) would grant language any human act within a given social reality. "If we see, hear and feel, generally speaking, such as we do, it is greatly because linguistic habits in our community predispose certain interpretation choices." Such choices define a man as a being who performs human acts which identify linguistic habits, revealing the culture of a given community/society.

Analyzing language in line with social tradition, habits and manners that define a community made Benveniste a peculiar linguist who now inspires us to reflect on the most popular thing in Brazil - samba - from a linguistic perspective. That is because, such as Normand (2009), we believe language should never divorce its living phenomenon, which is man. From that point of view, we construct our research object. In a way, if we can construct our testimony about women's role in the constitution of traditional samba in this study, it is because language preserves values of an entire social reality, and because language is presented to us as a guide to every form of symbolization - let us consider the ongoing meaning of Baiana Mamas in samba culture.

Concerning formal organization, this paper is as follows: Further exploring the first words, section Language-society: the grounds of man discusses from a dialectic conception, the relationship between language and society based on Benveniste's 1968 article Estrutura da língua e estrutura da sociedade [Language Structure and Society Structure, free translation]. Following that, section The witness and the language of testimony is justified by the fact that it is due to the possibility of witnessing within language and through language that we discuss women's role and participation in traditional samba culture. We finish this paper with a peculiar witness in traditional samba who translates the personification of samba's feminine strength: We dedicate the last words to Mama Ciata. This text paves the way toward showing it is through language that those who take it to say something end up constructing meaning(s), testimonials of times, values, feelings, experiences, cultures subscribed within itself and which become possible of being said to the extent that speakers put themselves as subjects of what they are saying, and thus are subscribed in the possibility of life, in the possibility of saying, in the possibility of witnessing - in this case - every life involved in traditional samba.

\section{Language-society: the grounds of man}

During his talk at Linguistic Society of America, in 1928, Sapir announced that Linguistics began its scientific path from the comparative studies between Indo-European languages. The case of phonetic regularity, for instance, found in comparisons between Indo-European languages, regardless of the reality of the language, refers to a primitive or a "sophisticated" people, points out how illusory it is to analyze either language or culture facts without considering its peculiar "linguistic symbolism". Sapir, agreeing with Emile Durkheim's sociological theory, asserts "language is a guide for "social reality"' (Sapir, 1969, p. 20). Because human reality cannot be shortened to an immediate practice; human reality, social activities, i.e., life in its collectivity is mirrored in the words "or words silently suggest it."

Signification of words in the light of sociocultural behavior evokes the comparative Benveniste for whom the acknowledgement of the peoples and the movements of the institutions throughout time are understood by one reason: language. In $O$ vocabulário das instituições indo-europeias [Dictionary of Indo-European Concepts and Society], Benveniste (1995a, p. 317) relates facts of language to manners of life, to the social relations of institutions. Let us exemplify with the genesis of the word "free," convenient to a research whose object is samba. Being free means belonging to "an ethnic trunk assigned by a metaphor of vegetative growth. This belonging grants a privilege that a foreigner and a slave will never get to know." The latter, in opposition to the free man, is a "man without rights," since he is considered an "enemy," therefore, is excluded from the process of "community development." 
This is how Benveniste (1995a, p. 11-12, highlighted by us), studying languages in consonance with how society functions, searches to, "[...] through comparison and diachronic analysis, bring up signification where at first we had only designation."

Benveniste was so dedicated to the testimonies of language that, as an expert of many languages, he conjugated the theory with observations of cultural facts regarding peoples whose manners were so unusual that they would "discourage even ethnographers." The typed report Benveniste addressed to Edward F. D'Arms on February 5th, 1954 is a testimony of such an experience, reporting his contact with Tlingit Indians from Alaska, considered "the most averse to research." In this document, Benveniste (2014, p. 219) confesses, "I was lucky to get them to accept my questions and get precious information from them about the themes that interested me." Being trusted by Tlingit Indians, the linguist visited the clans ceremony houses, got to know the "ritualistic objects and masks," which according to him were not shown to foreigners. All this experience was, in Benveniste's words (2014, p. 219), "dedicated to language."

Peoples habits interested Benveniste (2014), while cultural facts constituted language facts. This experience is also in Vocabulário das instituições indo-europeias [Dictionary of Indo-European Concepts and Society], when the comparative Benveniste dedicates himself to analyzing, from within languages, the vocabulary of these peoples related to the evolution of institutions, rituals, and culture. In this sense, Benveniste's experiences in getting to know real closely the languages of man witness the presence of man in language since always.

And it is not only the language Benveniste who certifies the necessary relationship between language and society. The articles in part six of Problemas de Linguística Geral I - Léxico e Cultura [Problems in General Linguistics] show a Benveniste who finds in use offorms the foundations of social structures. An example is the use of the term hostiles in Rome, or even the intralinguistic analysis of the term city in a two-model scheme - Greek and Latin. ${ }^{2}$

Benveniste's interest in peoples' social life with the purpose of studying language is undeniable. In Estrutura da língua e estrutura da sociedade [Language Structure and Society Structure, free translation], Benveniste (1968) takes language and society in a strictly necessary relationship; one is not conceived without the other. Language and society are taken in a semiological relationship - of interpretant and interpreted. ${ }^{3}$ Affirming that language interprets society means that society is within language.

In this sense, Benveniste gets away from the historic conception of language and society, given that at this level one cannot establish any relationship. On the other hand, language and society, when one takes them at a fundamental level, one can soon realize the homology between the two institutions (Benveniste, 1968/2006). Both language and society are part of human unconsciousness, and both co-exist by the same principle: that of collectivity. Such a principle, already discussed in Curso de linguística geral [Course in General Linguistics], is the reason why "the social fact might alone create a linguistic system. Collectivity is necessary to establish the values whose only reason to be is in use and general consensus: the individual alone is incapable of fixing even one" (Saussure, 2006, p. 132). We stress out that in Curso de linguística geral [Course in General Linguistics] (Saussure, 2006, p. 17) that dimension of collectivity is very dear to us to the extent that, for Saussure, language is "[...] a social product of the faculty of language and a set of necessary conventions, adopted by the social body to allow for the individuals to carry out such a faculty [...]" and "[...] it remains furthermore to the individual domain and the social domain; it does not allow to be classified in any category of human facts, because one does not know how to infer its unit." This is what we want to deal with: From this amalgam language, culture, society, which is not defined by itself, we want to investigate and watch as Benveniste - the man, who lives in society, is in language, therefore language interprets him.

What is presented in Curso de linguística geral [Course in General Linguistics] about the linguistic value gives us a heads-up about the reason why language is the interpretant of society: it "provides the constant and necessary basis of differentiation between individual and society. I mean language itself, always and necessarily" (Benveniste, 1968/2006, p. 98). This is the moment when Benveniste (1968) alludes to Saussurian principles concerning what there is dearest in Curso de linguística geral [Course in General Linguistics]: the paradoxical notion of linguistic value.

\footnotetext{
${ }^{2}$ Specifically, the essay Doismodeloslinguísticos da cidade, 1970 [Two Linguistic Models of the City, free translation], honoring Claude Lévi-Strauss. In this work, one might notice an analysis from the intralinguistic dimension pointed out in Semiologia da lingua, 1969 [Semiology of the Language]. Therefore, it is not about naming the object, but rather about a relationship between the very own structure of language and a derivative.

${ }^{3}$ Here we have an embryonic concept of the principle of interpretance of language, which was further developed a year later in Semiologia da língua [Semiology of the Language]. At that time, Benveniste (1969/2006, p. 55) did not understand language only as interpretant of society - as in the 1968's work. Instead, the author rises it to "a particular situation in the universe of the sign systems," [uma situação particular no universo dos sistemas de signos], because language is "the interpretant of all the other systems, whether they are linguistic or non-linguistic.” (Benveniste, 1969/2006, p. 61).
} 
At the same time that only to language the possibility of being interpretantis granted, because it "[...] functions as a machine to produce meaning,"expressly, it constitutes a system. Linguistic value "is only truly determined by the concurrence of what there is outside [language]," that is, in the relationships of the discourse (Saussure, 2006, p. 134). Let us take Saussure's very own example: One cannot immediately fix a value to the word sun without considering what surrounds it; and that is because "there are languages in which it is impossible to say "to sit by the sun" (Saussure, 2006, p. 135). The same happens to "the testimonies that language provides [...], [they] acquire their entire value if they are connected between them and coordinated to their reference" (Benveniste, 1968/2006, p. 100). Therefore, Benveniste (1968/2006) mentions the fact that we have language and society, and he justifies that the diversity of the references we may attribute to them constitutes the testimony of the subject who uses the forms. And this reality of language whose testimony is only possible when enunciated makes us go back to two issues in Curso de linguística geral [Course in General Linguistics] that certify the unique place of language as interpretant: Language as a system is accountable for the first place in the study of language; "it is language as a system that makes the unit of language" (Saussure, 2006, p. 18). Thus, language in itself is a whole.

Even though the topic society is a bit polemic in Benvenistian theory (Flores, 2013), Benveniste's analysis on relationships between language and society, from subjective and referential reality of discourse, is strongly supported in Saussure, especially related to the synchronic valueof the signs. And it is specifically at this point that Benveniste (1968/2006) meets Saussure to find common criteria between the system of the language and the system of society in a relationship of interpretant and interpreted, respectively.

If "nothing can be understood that has not been reduced to language," because while language is means through which the facts of the world and human experience - subject's and society's - are described, language-society is not a title with juxtaposed terms. It is about same natured notions finding in the possibility of subjectivity reasons for existence: "it is the inclusion of the speaker in their discourse that places the individual in society." By owing language, man "includes himself in relation to society and nature, and he necessarily puts himself in a class" - of authority or production (Benveniste, 1968/2006, p. 101). Therefore, when enunciated language carries new values which are not closed up in the significance of the system, but rather, according to Saussure (2006), complete each other with an element imposed from outside - by the subject who uses the forms. This gap between signification and value in language is what allows us to approximate language and society, more specifically, to witness society and culture in language, where man is - the witness. And as we restlessly find in Curso de linguística geral [Course in General Linguistics]: it is necessary to put yourself first in grounds of language as a system and taking it as a pattern for all other manifestations of language (Saussure, 2006, p. 16-17). Why not take it as a space to witness experiences, human and feminine experiences in traditional samba?

\section{The witness and the language of testimony}

In chapter five of Os afogados e Os sobreviventes [The Drowned and the Saved], Primo Levi describes several forms of useless violence in concentration camps, among which is tattooing. It was not a painful experience, but rather a traumatic one. Trauma laid on the nefarious symbology undermining man to animal condition. He was deprived even from his name, and the only language that was left for him was a non-verbal form printed on his skin. When there was truce, Levi (2004, p. 103) remembers, “[...] forty years afterwards, my tattoo became part of my body. [...] Young people often ask me why I do not get it removed, and this awes me - why should I? Not many of us in the world carry such testimony."

Agamben (2008) developed reasoning about notions of testimony and witness from Primo Levi and his experience as a concentration camp survival. In chapter four, $O$ arquivo e o testemunho [The Archive and the Testimony], in $O$ que resta de Auschwitz [Remnants of Auschwitz], Agamben (2008, p. 146) defines testimony as "[...] system of relationships between inside and outside the langue, between the sayable and the not sayable in every language - that is, between power of saying and its existence, between possibility and impossibility of saying." The idea of witness, whose origin is related to the Latin term testis, superstes and auctor ${ }^{4}$, is of our interest to the extent that traditional samba, seen from the enunciation perspective, implies the relationship between man, language and society.

\footnotetext{
${ }^{4}$ Thus Agamben (2008, p. 27) conceptualizes these categories representing witness: Testis comprehends, "etymologically those who present themselves as a third party in a process or a litigation between two contenders". Superstes "indicates that who has lived something, has gone through the end of an event and, therefore, might give their testimony" [indica aquele que viveu algo, atravessou até o final um evento e pode, portanto, dar testemunho disso]. "Auctor indicates the witness, while their testimony always presupposes something - a fact, something or a word - that pre-exist to them and the reality and strength of which should be validated or certified" (Agamben, 2008, p. 150). Primo Levi mainly represents superstes, who, by living in Auschwitz's system, only tries to "survive at any cost, that is, at the cost of understanding and also communicating with others." (Gagnebin, 2008, p. 13).
}

154 
In addition, we take a special look to women who witnessed the formation of samba culture and signed within language the values that were inherent to their experience within samba language and culture.

In a concentration camp, to witness is to not live. A Muslim, therefore, represents the non-man, his life is reduced to the underground. He is merely a voiceless body, without speech. His report, his testimony are null, because should he perform one, he dies. However, the Muslim would be the legitimate witness, once he is the only one who could fully report the experience. Impossible: The Muslim will be dead.

This totalitarian privation of language, speech and life around the Muslim is what builds the witnessing of that who survived, even if he does not correspond to an authentic witness. Primo Levi's paradox is established the moment there could not be true testimony and witness, "because the only ones who could be authentic witnesses were killed - such as the Muslims and many others" (Gagnebin, 2008, p. 15-16). Those who survive cannot give their full testimony. Thus,

[...] testimony is the gathering of two impossibilities of witnessing; language, in order to witness, should allow nonlanguage space, show the impossibility of witnessing. The language of the testimony is a language that no longer means, but that in this act of not meaning advances in the languageless until recollecting something else that is meaningless - the full witness - that of someone who by definition cannot witness. [...] The sign, which language deems to transcribe from the non-testimony, is not this word. It is the word of the language, that which is born where language is no longer in its beginning, it derives from that in order to - merely - witness; "it was not light, but it was there to witness light." (Agamben, 2008, p. 48).

Facing this paradoxical construction from which a testimony is performed, we ask: What about the subject? How do we conceive the notion of subject from Primo Levi's paradox? At this moment, Agamben (2008, p. 119) agrees with Saussure's ideas about linguistic sign that nothing in language "enables us to predict and understand how and due to what operations these signs will be put into action to integrate the speech." He then quotes Benveniste to remind us that the world of sign is closed within itself.

Agamben's enunciation (2008, p. 120), which refers to the fact of having a place, implies a paradoxical movement. For the author, the passage of language to discourse also constitutes a paradoxical act. And this is because it "implies at the same time a subjectivation and a desubjectivation."Once $I$ and you refer solely and exclusively to the instance of discourse, the subject of enunciation corresponds to the individual who identifies with $I$ only in the instance of discourse. This subject, therefore, should desubjectivate himself from any reference which is not related to the instance of discourse; he should "deobjectify himself as a real individual." So, the subject for Agamben (2008, p. 121) is also constituted from a paradox. And this is because, in the context of enunciation, the individual is not the one who speaks, but rather language is. The subject of the world is quiet, because he grants his voice to another - he grants his voice to the subject of enunciation who due to his being "fully constructed of discourse and through discourse, but exactly because of this, within discourse, cannot say anything, cannot speak."

However, if we consider Agamben's reasoning (2008, p. 125) about an idea almost fascist, since "men are men while they provide a testimony of the non-man," let us remember that he is the one who defends childhood as related to someone without language. Here lies, therefore, the assumption that man is only constituted as such due to language. There is nothing left from Hurbinek - or is there? - but his testimony enunciated by Levi. And in this gap between langue and parole lies the subject of enunciation, which is constituted while his figure always implies an impossible act of witnessing which is previous to him.

Such as language is fascist ${ }^{5}$, thus said Barthes, society is fascist to the extent that the thesis of testimony is declared as: "men are men while they are not human" (Agamben, 2008, p. 125). Discursive reality should then be understood as a possibility — not as an impossibility — of a man becoming subject within and through language. It is through discourse that man inserts his discourse in the world here and now. It is man's only way to survive and live. Thus, the possibility of speaking is not constituted due to a contingency. The very possibility of not being by enunciation enables the possibility of being, which is the subject of the following section. It is a female character in the history of samba in Brazil who, due to language, we understand witnesses something previous: traditional samba, by Mama Ciata.

\section{Mama Ciata, a peculiar witness in traditional samba}

Bare in mind a late-nineteenth-century Rio de Janeiro immortalized both by the way people think about it and the language of samba culture:

\footnotetext{
${ }^{5}$ Once language has a place, subjectivity is assumed. Thus, the subject of enunciation is desubjectivated as he makes language speak. It is not the subject who speaks, but language (Agamben, 2008).
} 
This was Praça Onze. It was the capital of a kingdom called Pequena África. An imaginary kingdom which gathered a great part of the black people who lived in Rio de Janeiro in the years that followed the abolition of slavery. A kingdom that would follow mother Africa's religion, art, and cuisine. A kingdom where I was the queen. When I got here in late nineteenth century I was already a grown woman. I came from Bahia, where Orishas presented me with the gift of making delicacies. I used to cook candies at home and sell them on the streets. At that time, I lived and worked downtown. It was almost the beginning of the twentieth century when I moved to Praça Onze. Business was doing well. My house was big. I was an expert at throwing parties, whether for Orishas or even for people. There was always food on the stove and music all around the house, from chorinho to partido alto. Boys such as Pixinguinha were always there; they were good musicians. [...] I died before the samba school parades were on, but I have lived in every Baiana who steps the avenue. I am Mama Ciata. I'm a black, Brazilian citizen. Orishas and people are the same when it comes to parties: They all love it., ${ }^{6}$

Mama Ciata lives by the voice of Leci Brandão, and the late-nineteenth-century, mid-twentieth-century Rio de Janeiro landscape by her, depicting a scene with peculiarities which have been immortalized in people's imaginations. Heitor dos Prazeres ${ }^{7}$ named it Pequena África. Geographically speaking, it was the area from the port all the way to Cidade Nova, the capital of which was Praça Onze (Moura, 1995).

Pequena África: Home of the black people descending from slaves, of spicy flavors in African-Brazilian dishes, and of the cult to the Orishas, of cachaça and parties. Although the name is singular - Pequena África - we should not consider it under a homogenized and single ideal. This Africa which was set in Rio de Janeiro was not solely populated by black people from Bahia; the place encompassed other groups as well, such as Jews, half-breeds, former slaves coming from other land in the Northeast. Therefore, it makes sense for us to think about Pequena África as the result of a "multiethnic territory," a space that gathered "hybrid and heterogeneous groups forming "this set of black squares ${ }^{8}$ in the city of Rio de Janeiro" (Nogueira; Silva, 2015, p. 22). Post-abolition historical context - the lack of enough jobs for the great masses of free workers in Bahia - strongly contributed to the population moving to Rio de Janeiro, searching for new means of survival. Prior to that, "black squares," in addition to encompass unique places of permanence, also propitiated multiethnic relationships, knowledge, affectivities and cultural strategies to new-coming black people in a context where what ruled was the aesthetic project of urbanization, from purely racialized theories disguised in the discourse of sanitation of African descendants.

This project of transforming Rio de Janeiro in a "possible Europe" (Moura, 1995, p. 47) was built by the mayor at the time, Pereira Passos". The elimination of tenements in the central area of the city was among several measures praised by the elite targeting an "art-noveau." Literally a "pull-down" movement took place, compromising the poor population of Rio de Janeiro. When the most famous of them was pulled down - Cabeça de Porco ${ }^{10}$ - dwellers went up Morro da Providência.

${ }^{6}$ Leci Brandão'shomageto Mama Ciata. BRANDÃO, Leci. Tia Ciata, Hilária Batista de Almeida (1854-1924) - Heróis de Todo Mundo. [Mama Ciata, Hilária Batista de Almeida (1854-1924)_Heroes of Everyone, free translation]. April 14, 2012. Transcribed by us. Available (in Portuguese) at: < http://www.heitordosprazeres.com.br/index.asp >. Accessed on: May 5, 2017.

${ }^{7}$ Heitor dos Prazeres (1898-1966) was born in Rio de Janeiro and grew up around Mangue and Praça Onze. Always attending samba circles at Mama Ciata's, he became representative of cavaquinho. As a composer, he stood beside notable samba composers such as Noel Rosa. In the 1930s, he began to depict the world of favela samba in his paintings, highlighting the characters of mulata and trickery (Prazeres, 2016).

${ }^{8}$ Nogueira e Silva (2015, p. 20) define "black squares" as "multiple, fluid, moveable, flexible movements, affective connections that have their own dynamics of resistance of the post-abolition scenario."

${ }^{9}$ One of the mayor's investments targeted " $[\ldots]$ building a coastal road - Beira-Mar - and grounding a large path of beach, which opened the way for the elites to occupy the Southern Area. In turn, the design of Avenida Central (future Avenida Rio Branco), crossing Rio de Janeiro from sea to sea, abolished part of the ancient downtown design, swallowing everything around. To the poorest, the options were to continue going up the hills, spreading around suburbs, or to improvise collective housings in the big houses which survived the greed of the pickaxes after being abandoned by their original owners, the new inhabitants of the art nouveau mansions in Botafogo, Flamengo and, further, Copacabana" (Neto, 2017, p. 49-50)

${ }^{10}$ The tenement was formed by "hovels, coach houses, stables, pigpens and sheds, at Rua Barão de São Félix, in the heart of Pequena África". The press at the time would describe it with adjectives such as "hiding place for bandits and murderers", "world of filthiness", "negative certificate of our civilization and good sense on the matter of hygiene". The population who inhabited Cabeça de Porco was around two thousand people, a great part was of blacks and mulatos, "people who would swell the legion of stevedores, construction workers, seamstresses, street vendors, woodworkers, confectioners, shoe makers, washwomen, bricoleurs, whores, pickpockets, prayers, teasers, window-jumping thieves, and general unemployed of the city". Cabeça de Porcowas pulled down on the night of January 26, 1893 (Neto, 2017, p. 34-35).

156 
There was no truce for demolitions and other removal processes were carried on, pushing "other poor people from the city uphill" (Neto, 2017, p. 36). That is what happened to Santo Antônio, São Carlos, Borel, Formiga, Macaco, Mangueira, and Salgueiro (Neto, 2017).

And thus the Carioca landscape was reshaped, and the population of Pequena África, in addition to spreading around central hills, occupied distant suburbs populated by "blacks and half-breed people, and former slaves, many of which came from the decaying coffee area Vale do Paraíba." In this sense, as well, literature argues for the existence of "little Africas" instead of "Pequena África [Little Africa]", "unique, idealized and exclusively in the area next to the port" (Neto, 2017, p. 37-38).

Modernity and "civilization," at the time, had the purpose of "de-Africanizing the capital of the Republic" (Neto, 2017, p. 34). Facing such a mission, Rio de Janeiro, under Republican regime (1889), was being built upon positivist ${ }^{11}$ principles which were printed in the national flag: a Brazil of "order and progress" (Neto, 2017). Against this ideology, the landscape of tenements represented delay, "an evil to be extirpated, such as a disgusting tumor," due to "new times and renovating winds of the new civilizing model" (Neto, 2017, p. 34). At the time, Pequena África was seen by the press as a threat to the "civilizing status" so eagerly expected by the government project and the Carioca elite.

This is the scenario where urban samba was born, from remodeling strategies of the city's landscape and under the atmosphere of the post-abolition context. The dissemination of Carioca samba happened concurrently with the dynamics of urbanization in Rio de Janeiro. Particularly, we agree with the idea that "samba is more than a music style. It is a life aesthetics. It has great importance in the formation and affirmation of ethnic groups in the city, and it is related to the idea of belonging in connection with a group or a specific symbolical place" (Nogueira; Silva, 2015, p. 23). This relationship has to do with the group which previously populated Pequena África, the central region of Rio de Janeiro where black people from different places gathered along with specific cultural rituals - samba circles, for instance.

Beyond Pequena África, even though samba composers were originally gathered in Carioca central area - until midtwentieth century - transformations through urbanization projects moved samba to other spaces in the city, specifically to the hills. "The city was crossed by samba, and samba crossed the urbanization process with all its strength, resistance and strategies" (Nogueira; Silva, 2015, p. 23). It meant a spread of diverse habits, relocating samba to other territories in a scenario of resistance and "de-Africanization" of Rio de Janeiro.

Tenements, quilombos, brothels, caboclo houses, candomblé courtyards constituted the multiethnic space that belonged to Pequena África, whose identity is characterized by quite heterogeneous manifestations coming from art and religion. And samba in its primary ${ }^{12}$ meaning is directly related to that instance of different representations. We cannot, therefore, delimitate a moment or a specific space regarding its birth; its genesis is linked to a "circuit of black squares in the City of Rio de Janeiro" (Nogueira; Silva, 2015, p. 28). Mama Ciata's home was then secured as a meeting point for the great witnesses of the world of samba, such as the so called SantíssimaTrindade [Holy Trinity], which was made out of Donga, João da Baiana and Pixinguinha, within the diasporic circuit which encompassed Pequena África. In this sense, we can understand it, according to Nogueira and Silva (2015, p. 27), as "a non-crystallized point of the tensions of this multiethnic territory which moves within a rhizomatic hybrid network fully decentered." And it is within this spirit of collectivity that samba is subscribed as a unique expression of a community grounded in a territory filled with cultural values and art, ethnic, and religious manifestations (Nogueira; Silva, 2015).

In such a context, Mama Ciata's Home is just an example ${ }^{13}$ crystallized in the collective memory as an in-between place of stories, cultures and different peoples. Pequena África and Mama Ciata's Home comprised fictional spaces while Carioca urban samba was being established, although its origin is far from precise. In this collective scenario of representation, we prefer to speak about historic possibilities marked by the heterogeneity of batuques that invaded further and further the streets of the central area of Rio de Janeiro, having Mama Ciata's home as reference. After all, who was the famous Mama Ciata? Who was this character? Born in Salvador in 1854, she was "the most famous of all Baianas, the most influent. [...] Hilária Batista de Almeida, Mama Ciata, remembered in every report of the emergence of Carioca samba and ranchos, where her name appeared written as Siata, Ciata, or Assiata" (Moura, 1995, p. 95).

\footnotetext{
${ }^{11}$ Lira Neto (2017, p. 34) refersto Frenchman Auguste Comte. The Republican regime was supported on Comte's maxim: "Love as principle, order as base, and progress as goal".

${ }^{12}$ This is about a time when samba was not yet considered a musical genre, but rather just a way of dancing, a form of partying.

${ }^{13}$ In addition to Mama Ciata, other black women, the so called "mamas" [tias] by the community, had their presence marked in the space of Pequena África: Mama Bebiana, Mama Celeste, Mama Dadá, Mama Davina, Mama Gracinda, Mama Mônica, Mama Perpétua, Mama Perciliana, Mama Sadata, and Mama Veridiana.
} 
Mama Ciata moved to Rio de Janeiro at the age of twenty-two years old, bringing her notorious knowledge about religion and culinary. Along with other Baiana mamas, she mastered the art of making delicacies, an activity rooted in religious foundations of typical Bahia habits.

The Baiana delicacy-cook, always typically dressed - round skirt, bright cotton shawl, and turban (Moura, 1995) dedicated herself to the cult of Orishas ${ }^{14}$ as a tradition inherited from her culture still in Baiana lands. For instance, Friday was Oxalá ${ }^{15}$ day, to whom she offered "cocadas and white delicacies" (Moura, 1995, p. 97). Ciata de Oxum ${ }^{16}$ was a party person always present in feasts dedicated to Orishas, which took place in Praça Onze. "She was a master of partido-alto songs, responding to the choruses in the parties, which went on for days, some of the attenders leaving for work and coming back, Ciata caring that every pot was always re-heated, so that samba never died" (Moura, 1995, p. 99). We realize that samba at parties thrown back then was not far from the African religious expressions, because samba had not yet become an object of consumption of the mass industry; it was part of a whole set of representativeness, singularizing black people who had just arrived in Rio de Janeiro in late-nineteenth century. Samba was then set as a common link of a collectivity built in an African continuum that strongly influenced the ways Brazilian black people socialized. Particularly, the space around Mama Ciata's home represented "all the strategy of musical resistance to the marginalizing curtain pulled up against the black after Abolition" (Sodré, 1998, p. 15). Samba was life itself represented and interpreted by language.

Mama Ciata's home served as a stage to the great representatives of samba, such as Donga, João da Baiana, Pixinguinha and Heitor dos Prazeres, who attended samba circles, learned Baiana culture and guaranteed a whole Carioca touch to Brazilian music. It was at Mama Ciata's that the first samba was created. PeloTelefone, whose authorship was attributed to Donga, is the embryo mark of samba as a musical genre.

From sambas in courtyards, parades of ranchos and processions in Marquês de Sapucaí, a lot of samba was made with different rhythms and distinct influences. Nowadays, samba schools, for instance, no longer have pastoras de terreiro [courtyard shepherdesses]. Courtyard samba is no longer present in the space of schools; however, the memory of women mamas is still there today in each female Baiana that steps the avenue during Carnival parades all over Brazil, witnessing a time, a history, an origin, a female presence, that of Mama Ciata. It is the testimony, not because it is dead - such as the Muslim, in the work by Primo Levi - but rather, a testimony for being alive. It is a testimony in discursive reality while being the possibility of a man becoming subject within and through language - the language of traditional samba.

\section{Final words}

With intents to address the role of women in the consolidation of traditional samba herein personified as Mama Ciata, we would like to highlight two considerations. The first one concerns the starting point to this study, our methodology to organize our research: the relationship between language and society.

Samba, a cultural expression and an outcome of sociability, moves around a series of symbols - religion, culinary, body, habit, space related - crystallized in samba composers' music as valuable signs. Mama Ciata's home, in samba identity terms, was not only a space where meetings and parties took place in Pequena África community; but rather, Mama Ciata's home survives up to now in the language of those who live samba.

\footnotetext{
${ }^{14}$ These are "supernatural entities, avatars of ancestors divinized or representatives of nature forces, the cult of which came to Brazil and other countries of America with enslaved Africans in the Bight of Benin, Western Africa" [entidades sobrenaturais, avatares de ancestrais divinizados ou representantes de forças da natureza, cujo culto chegou ao Brasil e a outros países das Américas com africanos escravizados no golfo de Benim, África Ocidental] The word "Orisha" is about "divinities, male, female or double nature, of Yoruba or Nagô origin, worshiped in Baiano Canbomblé, in Xangô from Pernambuco and other forms derived from them" (Lopes; Simas, 2017, p. 201). Orishas have been a recurrent theme in samba schools since 1966.

${ }^{15}$ Considered the most powerful of Orishas and the most worshiped in Baiano Candomble and related to Jesus Christ in the syncretism, Oxalá “ [...] dominates the creation as a whole, life and death". His basic elements are water, earth and air. In Brazil, most of Oxalá's African peculiarities, including his primacy over the other Orishas, the white color and his power in creation, are preserved (Berkenbrock, 2012, p. 249).

${ }^{16}$ Considered the most beautiful and seductive, but also vain and jealous, Oxum is Xangô's second wife. In Brazil, she is identified "with rivers and fresh water in general"; therefore, she is a symbol of pregnancy and fertility. Her colors are yellow and red. In syncretism, Oxum comprehends the different images of Mary (Berkenbrock, 2012, p. 239-240).
} 
For example, in Paulo César Pinheiro's composition Portela na Avenida, which has become an anthem of the samba universe so to speak, we come across signs of the language, such as blue and white cloak [manto azul e branco], prayer [reza], procession [procissão], sentinel [sentinela], Holy Spirit [Espírito Santo], temple [templo], faithful [fiéis], mass [missa], among others, which signify and are part of the meaning in religious discourse.

Thus, we find ourselves in the plane of significance of language. On the other hand, in a Carnival context, these same signs complete each other in terms of value, because they carry the significance of enunciation, of a subject who owns his language and enunciates himself in society. In the semantics of samba, the white and blue cloak refers to the colors which symbolize Portela, prayer is the samba sung by members, Holy Spirit becomes the eagle of the association, sentinel is the Velha-Guarda [Old Folks] overseeing the school (true witnesses). The enunciation of what is sacred becomes the enunciation of what is profane. The interpretance of language, then, is found in this metalinguistic faculty of speaking-of-itself. It is the action of the speaker which mobilizes language by its own and becomes subject of (its) enunciation. At this point Benveniste's claim (1968/2006, p. 100) that, "[...] the testimonies that language provides only acquire their entire value if they are connected between them and coordinated to their reference" makes all sense. This meaning interests us, and from this meaning the concept of testimony, which we have addressed previously in this paper, especially interests us.

The second and last issue concerns what we described here as social fact to be analyzed in the lights of linguistics: the role of women in the constitution of traditional samba. From the principle that language works as a meaning-producing machine, that it is the only interpreting system because it contains society, and relating the binomial language and society to the reasons why a man constitutes himself as a subject, Mama Ciata, the witness (superstes) which we refer to, was a subject that marked within language and culture her singularity, because she lived samba. "Revered as a queen," her "bountiful tray of cakes and delicacies, cocadas and colorful sweets was always an attraction" (Centro Cultural Cartola, [s.d.], p. 16). Always dressed in her Baiana outfit, the mãe-de-santo followed her daily ritual selling her delicacies without ever letting aside her homage to the Orisha of the day. Mama Ciata lived in Carioca society in a time marked by displeasures, witnessing the survival of samba in a space - Pequena África - where her people and her culture were absolutely denied by the majority. Her symbology conquered Brazilian music and is crystallized in the way people think about it. Today, the testimony of mamas such as Ciata is present in the man who, by owning the forms of language, enunciates his samba and himself as subject in society, turning himself into a testimony.

\section{References}

Agamben, Giorgio. 2008. O que resta de Auschwitz: o arquivo e a testemunha [Remnantsof Auschwitz]. Translated into Portuguese by Selvino J. Assmann. São Paulo: Boitempo.

Benveniste, Émile. 1995a. O vocabulário das instituições indo-européias. Economia, parentesco, sociedade. [Dictionary of Indo-European Concepts and Society]. Translated into Portuguese by Denise Bottmann. Campinas, SP: Ed. da Unicamp, v. 1.

Benveniste, Émile. 1995b. O vocabulário das instituições indo-européias. Poder, direito, religião. [Dictionary of IndoEuropean Concepts and Society] Translated into Portuguese by Denise Bottmann and Eleonora Bottmann. Campinas, SP: Ed. da Unicamp, v. 2.

Benveniste, Émile. 2005. Problemas de linguística geral I. [Problems in General Linguistics] 5. ed. Translated into Portuguese by Maria da Glória Novak and Maria Luisa Salum. Campinas, SP: Pontes Editores.

Benveniste, Émile. 2006. Problemas de linguística geral II. [Problems in General Linguistics] 2. ed. Translated into Portuguese by Eduardo Guimarães et al. Campinas, SP: Pontes Editores.

Benveniste, Émile. 2014. Últimas aulas no Collège de France: 1968-1969. [Last Classes at Collège de France (1968 and 1969), free translation]. Translated into Portuguese by Daniel Costa da Silva et al. São Paulo: Unesp.

Berkenbrock, Volney J. 2012. A experiência dos orixás: um estudo sobre a experiência religiosa no candomblé. [The Orishas Experience: A Study on the Religious Experience in Candomblé, free translation] 4. ed. Petrópolis, RJ: Vozes.

Centro Cultural Cartola. A força feminina do samba. [Samba's Feminine Strength]. Rio de Janeiro: Centro Cultural Cartola; Secretaria Especial de Políticas para as Mulheres, [s.d.]. (Idealized by NilcemarNogueira and Helena Theodoro).

Gagnebin, Jeanne Marie. 2008. Presentation. Agamben, Giorgio. O que resta de Auschwitz: o arquivo e a testemunha [Remnantsof Auschwitz]. Translated into Portugueseby Selvino J. Assmann. São Paulo: Boitempo.

Levi, Primo. 1998. É isto um homem? [Is This a Man]. Translated into Portuguese by Luigi Del Re. Rio de Janeiro: Rocco. 
Levi, Primo. 2004a. Os afogados e os sobreviventes: os delitos, os castigos, as penas, as impunidades. [The Drowned and the Saved] 2. ed. Translated into Portuguese by Luiz Sérgio Henriques. São Paulo: Paz e Terra.

Levi, Primo. 2004b. A trégua. [The Truce] Translated into Portuguese by Marco Lucchesi. São Paulo: Planeta de Agostini.

Lopes, Nei; Simas, Luiz Antonio. 2017. Dicionário da história social do samba. [Dictionary of Samba's Social History, free translation]. 2. ed. Rio de Janeiro: Civilização Brasileira. Awardedwith Prêmio Jabuti 2017.

Moraes, Vinícius. 2008. Samba falado: crônicas musicais (1913-1980). [Spoken Samba: Musical Chronicles (19131980). Rio de Janeiro: Beco do Azougue.

Moura, Roberto. 1995. Tia Ciata e a Pequena África no Rio de Janeiro. [Mama Ciata and Pequena África in Rio de Janeiro, freetranslation]. 2. ed. Rio de Janeiro: Secretaria Municipal de Cultura. (Biblioteca Carioca Collection; v. 32).

Neto, Lira. 2017. Uma história do samba: as origens. [A History of Samba: The Origins, free translation]. São Paulo: Companhia das Letras, v. 1.

Nogueira, Renato; Silva, Wallace Lopes. 2015. Praças Negras: territórios, rizomas e multiplicidade nas margens da Pequena África de Tia Ciata. [Black Squares: Territories, Rhizomes, and multiplicity in the margins of Mama Ciata's Pequena África, free translation]. In: Silva, Wallace Lopes (Org.). Sambo, logo penso: Afroperspectivas filosóficas para pensar o samba. [I do the Samba, Therefore I Think: Philosophical African Perspectives to Think Samba, free translation]. Rio de Janeiro: Hexis, Fundação Biblioteca Nacional, p. 19-30.

Prazeres, Heitor dos. 2016. Heitor dos Prazeres: músico, poeta, pintor. [Heitor dos Prazeres: Musician, Poet, Painter, freetranslation]. Rio de Janeiro. Available at: < http://www.heitordosprazeres.com.br/index.asp>. Accessed on: May $5^{\text {th }}, 2017$.

Sapir, Edward. 1969. Linguística como ciência. [The Status of Linguistics as a Science]. Translated into Portuguese by J. Mattoso Câmara. Rio de Janeiro: Acadêmica. (Philology and Linguistics, v. 1).

Saussure, Ferdinand de. 2002. Escritos de linguística geral. [Writings in General Linguistics]. Translated into Portuguese by Carlos Augusto LeubaSalum and Ana Lucia Franco. Organized and edited by Simon Bouquet and Rudolf Engler with the collaboration of Antoinette Weil. São Paulo: Cultrix.

Saussure, Ferdinand de. 2006. Curso de linguística geral. [Course in General Linguistics]. Translated into Portuguese by Antônio Chelini, José Paulo Paes, Izidoro Blikstein. Organized by Charles Bally, Albert Sechehaye with the collaboration of Albert Riedlinger. 27. ed. São Paulo: Cultrix.

Sodré, Muniz. 1998. Samba, o dono do corpo. [Samba, the Owner of the Body, free translation]. 2. ed. Rio de Janeiro: Mauad. 